\title{
PKM KULIT SUKAREGANG GARUT JABAR MENGANTISIPASI PRODUK IMPORT \\ MELALUI MANAJEMEN USAHA, TEKNOLOGI INFORMASI (IbM Kelompok Usaha Kreatif UMKM Industri Kulit di Sukaregang Garut)
}

\author{
R. Adjeng Mariana Febrianti \\ adjeng.mariana@widyatama.ac.id \\ R. Ait Novatiani \\ ait.novatiani@widyatama.ac.id \\ Sri Lestari \\ sri.lestari@widyatama.ac.id \\ UNIVERSITAS WIDYATAMA
}

\begin{abstract}
ABSTRAK
Garut merupakan salah satu kota yang berada di wilayah Priangan Timur, industri Kulit Sukaregang menghasilkan tas, sepatu, jaket, aksesories lainnya. Pertumbuhan iklim usaha di sektor industri kulit cukup lambat, hal ini terlihat dari lemahnya produk yang dihasilkan belum memiliki keunggulan. Akses pemasaran kesulitan menerapkan sistem pemasaran untuk meraih pangsa pasar yang diharapkan, skala Usaha Kecil Menengah memiliki keterbatasan khususnya konsep pemasaran belum diterapkan dengan semestinya, mengakibatkan produktivitasnya terhambat. Tujuan dari Pengabdian Kepada Masyarakat membantu memberikan pemahaman serta pelatihan bagaimana caranya membuat manajemen usaha yang menguntungkan di tengah persaingan demikian ketat dari industri kulit yang sama. Metode pelaksanaan yaitu memberikan pelatihan sesuai dengan permasalahan yang dihadapi, mekanisme pelaksanaan dari hulu ke hilir yaitu aplikasi manajemen usaha, ceramah dialogis, pelatihan dan pendampingan. Selain itu juga dilakukan evaluasi yang berkelanjutan untuk dapat mengatasi detail problematika faktual yang dihadapi. Solusi prioritas yang ditawarkan yaitu menerapkan konsep pemasaran terpadu (rencana jangka pendek, menengah, panjang), penerapan strategi pemasaran (kelompok pasar, target pasar dan posisi pasar), bauran pemasaran (produk, harga, promosi, distribusi) analisa SWOT (kekuatan, kelemahan, peluang, ancaman), strategi bersaing (strategi biaya rendah).
\end{abstract}

Kata kunci: industri kulit, konsep pemasaran, bauran pemasaran, strategi pemasaran, SWOT Analysis, strategi bersaing.

\section{PENDAHULUAN}

Industri kreatif pada umumnya banyak diciptakan oleh berbagai kalangan usaha baik pemula yang baru mulai usaha walaupun masih dalam skala Usaha Kecil
Menengah yang sudah mapan dengan skala ukuran besar berupaya membantu meningkatkan pendapatan daerah di mana usaha tersebut dilakukan. Pengembangan Usaha Kecil Menengah (UKM) merupakan usaha sederhana dengan modal 
terbatas namun dapat menghasilkan produk unggul dan mandiri. Pelaksanaan yang otodidak dapat membantu perekonomian daerah selain dapat meningkatkan keterampilan dalam memanage usaha di bidang produksi, pemasaran, permodalan dan tenaga terampil lainnya.

Home industry yang dipilih yang memulai usahanya di bidang produk atau jasa dapat membantu menciptakan lapangan kerja bagi masyarakat setempat, terutama yang berkaitan dengan pemberdayaan tenaga-tenaga muda yang masih berpotensi memajukan daerahnya. Pemberdayaan ekonomi kerakyatan, menjadi prioritas UKM di dalam menghadapi krisis keuangan global, selain mengurangi tingkat urbanisasi, dengan memberikan penyuluhan untuk meningkatkan pendapatan masyarakat setempat. Menanggulangi angka pengangguran yang kurang diberdayakan pemerintah daerah setempat, dengan menekan tingkat kemiskinan yang selama ini menjadi beban moral bagi masyarakat sekitarnya. Menyediakan lahan usaha bagi tenaga muda yang memiliki pendidikan formal, serta memotivasi pola pikir/paradigma sebagai seorang wirausaha yang tangguh, kuat, mandiri, kreatif, dan memiliki inisiatif yang terfokus kepada input - process - output

Garut merupakan salah satu daerah dimana industri kulit merupakan produk yang mampu diolah menjadi jaket, tas, sepatu/sandal dan lain sebagainya. Gencarnya produk impor yang membanjiri Indonesia khususnya China menawarkan produknya dengan harga yang sangat murah, desain bagus, harga variatif. Hal ini memotivasi perajin kulit di Sukaregang Leather Center untuk meningkatkan kemampuannya dan turut serta masuk dalam arena persaingan yang sangat ketat. Kegiatan Pengabdian Kepada Masyarakat adalah untuk mengembangkan UKM yang unggul dan mandiri secara ekonomi serta meningkatkan keterampilan dalam memanage usaha produksi, pemasaran, permodalan dan tenaga terampil lainnya. Home industry yang dipilih saat ini yang memulai usahanya di bidang kulit menghasilkan jaket, sepatu, dan tas yang di produksi secara tradisional tanpa berbekal keahlian/otodidak.

\subsection{Konsep Pemasaran}

Oliver dan Media Creative dua mitra yang menekuni usaha kulit dengan modal keluarga, produksi terbatas tanpa dibekali keterampilan yang khusus, walaupun dengan segala keterbatasan dan kesulitan yang hampir sama rata rata perajin kulit saat ini. Dilihat dari konsep usaha ke dua Mitra masih berfikir usaha jangka pendek yaitu penjualan hanya menunggu pelanggan yang datang ke gerainya. Tanpa memikirkan bagaimana mengembangkan usaha di masa yang akan datang yaitu perencanaan jangka menengah dan jangka panjang yangbbelum terealisisr dengan baik. Padahal menurut Basu Swastha dan Hani Handoko (2000:6) mendefinisikan sehubungan dengan hal ini dengan mengemukakan "konsep pemasaran adalah sebuah falsafah bisnis yang menyatakan bahwa pemuasan kebutuhan konsumen merupakan syarat ekonomi dan sosial bagi kelangsungan hidup perusahaan".

\subsection{Bauran Pemasaran}

Produk yang dijual masih dipasok oleh produsen lain, tetapi sebagian besar produksi sendiri. Bahan baku sulit diperoleh, tidak ada mesin modern yang membantu memperlancar produksi akibatnya menjadi terhambat. Promosi yang digunakan saat ini WhatsApp, BlackBerry Messeger, Facebook sehingga informasi produk yang disampaikan pada pelanggan sangat terbatas. Distribusi penjualan dilakukan 
secara retail, kedua Mitra kesulitan dalam pendistribusiannya terutama di daerah yang tidak terjangkau. Padahal Bandung, Tasikmalaya, Sumedang, Cirebon, Indramayu, Jakarta, Serpong, Bekasi merupakan langganan tetap dalam kurun waktu lama. Tempat bagi ke dua Mitra belum memiliki tempat penjualan yang memadai, hanya di komplek Sukaregang Leather Center, selain di rumah tempet proses produksi berlangsung. Hal ini sesuai dengan teori yang dikemukakan oleh (Kotler \& Keller 2016) merupakan suatu strategi penjualan atau promosi serta penentuan harga yang bersifat unik serta dirancang untuk menghasilkan pertukaran yang saling menguntungkan untuk pasar yang dituju.

\subsection{Strategi Pemasaran}

Kelompok pasar yang dituju kedua Mitra sama dengan pedangang lainnya yang mangkal di Kompleks Sukaregang Leather Center, karena rata - rata yang datang adalah yang memiliki kemampuan daya beli yang sama. Target pasar yang dituju selama ini adalah keluarga karena produk yang dipasarkan adalah untuk kebutuhan keluarga, sedangkan produksi kulit Sukaregang diposisikan untuk golongan menengah yang memiliki pendapatan, selera dan juga keinginan untuk membel. Makna dari strategi yaitu bagaimana caranya seseorang mamanage pemasarannya dengan baik, sesuai yang dikemukakan oleh Kotler \& Keller (2016) bahwa mamanage harus memiliki ilmu, seni memilih target pasar untuk mendapatkan, menumbuhkan, menciptakan, menyampaikan dan mengkomunikasikan kepada pelanggan.

\subsection{Analisa SWOT}

Industri kulit khususnya di
Sukaregang Leater Center Garut merupakan kawasan perdagangan yang selalu ramai dikunjungi para pelancong dari berbagai daerah yang sengaja datang untuk berburu kulit. Berbagai warna, corak dan desain ditawarkan dengan eragam harga yang disesuaikan dengan bahan baku yang dikeluarkan walaupun sebagian produk khususnya tas, sepatu dipasok oleh produsen yang sama. Oliver dan Media Creative belum sepenuhnya aktif memanfaatkan media social yang digunakan dalam mencari peluang - peluang, masih terdapat kelemahan dan ancaman dari perajin kulit yang ada di sekitarnya. Fungsi dari SWOT sebagai instrumen yang tepat dan bermanfaat dalam melaksanakan aktivitas analisis strategis, selain itu kedua Mitra belum bisa meminimalisir dampak ancaman atau kelemahan yang harus dihadapi. Menganalisis SWOT adalah suatu upaya yang dilakukan dalam kegiatan usaha untuk penetapan strategi bisnis. Biasanya, analisis ini menggunakan panduan sistematis atau kerangka dalam menjalankan diskusi agar lebih terarah dan fokus pada hal yang ingin dicapai. Analisis tersebut juga bisa dijadikan sebagai pertimbangan suatu perusahaan untuk mengambil keputusan dalam pengembangan bisnis yang dijalani, (Kotler \& Keller 2016).

\subsection{Strategi Bersaing}

Strategi bersaing adalah langkahlangkah strategis yang terencana maupun tidak terencana untuk dapat memiliki keunggulan bersaing sehingga dapat menarik perhatian konsumen, memperkuat posisi dalam pasar, dan bertahan terhadap tekanan persaingan (Hariadi, p.99, 2005). Bisnis yang memilih strategi memangkas beberapa atribut produk agar dapat meminimalisir biaya kemudian dapat menawarkan produk dengan harga lebih murah. 
Kedua Mitra juga belum sepenuhnya menerapkan strateginya yaitu memproduksi produk/jasa dengan biaya rendah, yaitu menggunakan bahan dibawah standar tetapi ada beberapa atribut produk diganti dengan produk subsitusi yang berimbas pada kualitas dari produk itu sendiri. Sesuai dengan teori yang disampaikan oleh (Porter, 2007) bahwa strategi bersaing dengan biaya rendah dapat menghapus atribut mewah pelanggan dengan menawarkan harga yang lebih rendah dari produk yang diproduksinya untuk mendapatkan hasil yang sesuai dengan keinginan pasar tanpa menghilangkan standar kualitas yang di rencanakan

\section{METODE PELAKSANAAN}

\subsection{Pendidikan masyarakat}

Metode pelaksanaan dari hulu ke hilir yaitu memberikan pemahaman tentang strategi yang akan diprioritaskan untuk dilaksanakan dengan ceramah dialogis dengan kedua Mitra selanjutnya dilakukan:

a. Pelatihan khususnya ilmu marketing dilaksanakan disesuaikan dengan kemampuan pola pikir kedua Mitra yang terbatas, tehnisnya di rumah tempat proses produksi berlangsung bahkan di gerai tempat penjualan produk yaitu di Sukaregang Leather Center dengan pemiliknya dan stafnya tentang bagaimana mengelola usaha yang profitable.

b. Intensitas pendampingan terstruktur disesuaikan dengan permasalahan yang dihadapi pada saat pelaksanaan proses produksi berlangsung yang terjadwal dengan materi - materi yang up to date.

c. Pemahaman tentang legalitas sebuah usaha tentang rambu - rambu identitas produk yang bisa dipertanggung jawabkan secara hukum dengan mendaftarkan Haki ke Dinas Hukum dan HAM. d. Evaluasi yang berkesinambungan dapat mengatasi detail problematika faktual yang dihadapi dengan mengontrol langsung ke lapangan berkaitan dengan prioritas masalah.

e. Kelengkapan manajemen usaha tidak cukup hanya pemasaran saja tetapi berkaitan dengan permodalan dan ilmu pengetahuan dan teknologi.

\section{HASIL PENGABDIAN PADA MASYARAKAT}

\subsection{Solusi danTarget Luaran}

Kedua mitra merupakan pelaku Usaha Mikro Kecil Menengah (UMKM) khususnya skala usaha kecil dimana usahanya masih dalam tahap berkembang sehingga untuk dapat memenangkan persaingan perlu diberikan wawasan konsep pemasaran yang terencana dalam jangka panjang, terutama membenahi internal marketing meliputi product, price, promotion, place dan mengantisipasi ekternal marketing meliputi ekonomi dan hukum, iptek, lingkungan (Kotler \& Amstrong, 2010). Selain itu juga perlu menerapkan strategi marketing yang tepat guna dan tepat sasaran yang efisien dan efektif sehingga pasar yang dibidik kedua Mitra sesuai dengan yang direncanakan. SWOT Analysis lebih berdaya guna untuk mengetahui sampai dimana kekuatan, kelemahan usahanya dengan memanfaatkan peluang yang menghampirinya dan mengantisipasi ancaman terutama dari pesaing yang ada di sekelilingnya. Strategi low cost tepat dilaksanakan dengan subsitusi dengan bahan baku, SDM kualitas sama tetap memiliki karakter yang tidak jauh berbeda. Sentuhan seni dapat membantu kedua Mitra dalam mengembangkan desain yang baru dan lebih dikembangkan menjadi desain - desain yang modern tanpa menghilangkan ciri 
khas dari masing - masing produk yang dihasilkan oleh kedua Mitra.

Tabel 1

Solusi dan Target Luaran

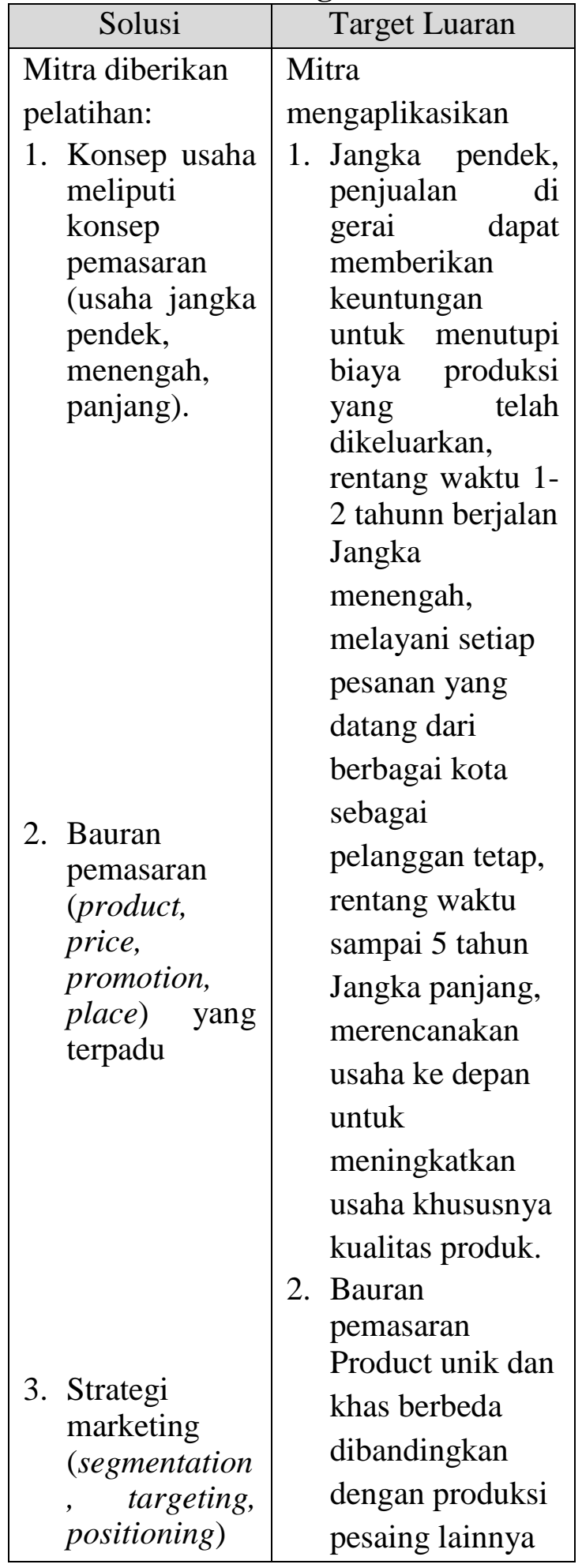

yang

profitable

4. SWOT

Analysis

(strength, weakness,

treath,

opportunities)

5. Strategi

bersaing

(strategi low

cost) yang

profitable
Price, sesuai

dengan biaya -

biaya yang

dikeluarkan

Promotion,

media social

yang tepat guna

dan tepat sasaran

Place, strategis

mudah dijangkau

3. Segmentation, mengelompokka

n konsumen sesuai dengan daya beli, usia, latar belakang, selera dll

Targeting,

membidik

konsumen tetap

sasaran

4. SWOT Analysis memperkuat internal (4P) dgn meminimalisasi kekurangan, dengan memanfaatkan peluang dengan meminimalisasi kekurangan dan menghadapi ancaman dari pesaing lainnya

5. Strategi berbiaya rendah mengganti bahan baku dengan barang subsitusi menghasilkan produk yang berkualitas, desain dan SDM yang terdidik

Sumber: Data Diolah 2019 
Tabel 2.2

Rencana Target Capaian Luaran

\begin{tabular}{|c|c|c|}
\hline No & Jenis Luaran & $\begin{array}{l}\text { Indikato } \\
\mathbf{r} \\
\text { Capaian }\end{array}$ \\
\hline \multicolumn{3}{|c|}{ Luaran Wajib } \\
\hline 1 & $\begin{array}{l}\text { Publikasi Ilmiah } \\
\text { pada Jurnal ber } \\
\text { ISSN/Prosiding }\end{array}$ & Publikasi \\
\hline 2 & $\begin{array}{l}\text { Publikasi pada } \\
\text { medi } \\
\text { masa/online/repo } \\
\text { citory PT }\end{array}$ & Terbit \\
\hline 3 & $\begin{array}{l}\text { Peningkatan } \\
\text { daya saing } \\
\text { (peningkatan } \\
\text { kualitas, } \\
\text { kuantitas, serta } \\
\text { nilai tambah } \\
\text { barang, jasa, } \\
\text { diversifikasi } \\
\text { produk, atau } \\
\text { sumber daya } \\
\text { lainnya) }\end{array}$ & $\begin{array}{c}\text { Ada } \\
\text { peningka } \\
\tan \end{array}$ \\
\hline 4 & $\begin{array}{l}\text { Peningkatan } \\
\text { penerapan iptek } \\
\text { di masyarakat } \\
\text { (mekanisasi, IT, } \\
\text { dan manajemen) }\end{array}$ & $\begin{array}{c}\text { Ada } \\
\text { peningka } \\
\tan \end{array}$ \\
\hline 5 & $\begin{array}{l}\text { Perbaikan tata } \\
\text { nilai masyarakat } \\
\text { (seni budaya, } \\
\text { social, politik, } \\
\text { keamanan, } \\
\text { ketentraman, } \\
\text { pendidikan, } \\
\text { kesehatan) }\end{array}$ & Ada \\
\hline \multicolumn{3}{|c|}{ Luaran Tambahan } \\
\hline 1 & $\begin{array}{l}\text { Publikasi di } \\
\text { jurnal } \\
\text { internasional }\end{array}$ & $\begin{array}{l}\text { Tidak } \\
\text { ada }\end{array}$ \\
\hline
\end{tabular}

\begin{tabular}{|r|l|l|}
\hline 2 & $\begin{array}{l}\text { Jasa: rekayasa } \\
\text { social, metode } \\
\text { atau system, } \\
\text { produk/barang }\end{array}$ & $\begin{array}{l}\text { Tidak } \\
\text { ada }\end{array}$ \\
\hline 3 & $\begin{array}{l}\text { Inovasi baru } \\
\text { TTG }\end{array}$ & $\begin{array}{l}\text { Tidak } \\
\text { ada }\end{array}$ \\
\hline 4 & $\begin{array}{l}\text { Hak kekayaan } \\
\text { intelektual } \\
\text { (Paten, Paten } \\
\text { sederhana, Hak } \\
\text { Cipta, Merek } \\
\text { dagang, Rahasia } \\
\text { Dagang, Desain } \\
\text { Produk Industri, } \\
\text { Perlindungan } \\
\text { Varietas }\end{array}$ & \\
& $\begin{array}{l}\text { Tidak } \\
\text { Tanaman, } \\
\text { Perlindungan } \\
\text { Desain Topografi } \\
\text { Sirkuit Terpadu) }\end{array}$ & \\
\hline 5 & Buku ber ISBN \\
\hline
\end{tabular}

\section{KESIMPULAN}

\subsection{Kesimpulan}

Berdasarkan pemaparan permasalahan tersebut diatas dapat disimpulkan bahwa untuk memulai usaha atau usaha yang sudah berjalan diperlukan manajemen usaha yang terstruktur dengan baik dan benar khususnya memiliki kunci - kunci sukses yang dapat mengantarkan kedua Mitra memanage usaha yang lebih menguntungkan bukan saja dalam jangka pedek, tetapi jangka menengah dan jangka panjang. Bauran Pemasaran, kedua Mitra masih kurang mengaplikasikan $4 \quad \mathrm{P}$ (product, price. Promotion, place) sehingga kurang maksimal mendapatkan profit sesuai harapan. Selain itu juga pelaksanaan strategi pemasaran (segmentation, targeting dan positioning) kedua Mitra tidak mengaplikasikan di lapangan yang tepat guna dan sasaran. SWOT Analysis kedua Mitra tidak mengetahui dan 
memahami apa yang dimaksud strength, weakness, opportunity, treath, padahal fondasi utama dalam sebuah bisnis adalah seberapa besar kekuatan dan kelemahan dari masing - masing, selain menciptakan dan mencari peluang - peluang yang ada di sekitarnya dan kesiapan untuk menghadapi setiap ancaman dari pesaing yang memproduksi produk yang sama. Begitu pula strategi bersaing dengan low cost dimana kedua Mitra belum menerapkan strategi tersebut untuk meraih pangsa pasar yang lebih besar.

\subsection{Saran}

Kedua Mitra disarankan untuk membenahi manajemen usaha di semua bidang khususnya usaha jangka menengah dan jangka panjang, eksistensi perusahaan lebih stabil apabila dibandingkan dengan jangka pendek. Bauran pemasaran lebih dimaksimalkan khususnya kualitas peroduk lebih ditingkatkan, harga disesuaikan dengan biaya yang telah dikeluarkan, promosi lebih ditingkatkan khususnya di media social dan publikasi di media masa. Strategi marketing ditingkatkan pemberdayaan baik kelompok pasar terutama memiliki daya beli, selera, usia, selain itu target pasar lebuh terkonsentrasi dalam satu kelompok, produk diposisiskan untuk golongan mana. SWOT Analysis, meningkatkan dan memperbaiki apa yang menjadi kekuatan perusahaan selain dari meminimalisasi kelemahan nya di segala bidang sehingga pada saat peluang menghampiri kedua Mitra harus sudah mempersiapkannya terlepas dari ancaman yang selalu mengikutinya. Begitu pula dalam strategi biaya rendah kedua Mitra disarankan untuk mengganti bahan baku dengan bahan subsitusi lainnya.

\section{DAFTAR PUSTAKA}

Basu Swasta dan Hani Handoko, 2010, Manajemen Pemasaran: Analisa dan.
Perilaku
Konsumen.
BPFE.
Yogyakarta.

Haryadi, Hendi. (2009). Administrasi Perkantoran untuk Manajemen \& Staf. Jakarta Selatan : Transmedia Pustaka.

Kotler \& Keller, 2016 "A Framework for Marketing Management", Prentice Hall International Inc. New Jersey.

Kotler\& G. Amstrong, (2010), "Principle of Marketing", $11^{\text {th }}$ ed., page, 13, 346, Prentice Hall Upper Saddle River, New Jersey.

Porter, Michael E., (2007), Competitive Advantage: Creating and Sustaining Superior Performance, New York: The Free Press. 